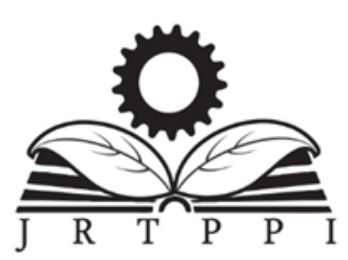

Vol. 10 No. 2 (2019) 1-6

Jurnal Riset

Teknologi Pencegahan Pencemaran Industri

Kementerian

Perindustrian

REPUBLIK INDONESIA

Journal homepage : jrtppi.id

\title{
Decolorization of Vat Violet 1 Dye from Textile Industrial Wastewater using Biofilm of Fungal and Bacterial Consortium
}

\author{
Lestari Wevriandini ${ }^{1}$, Erni Martani ${ }^{1}$ \\ ${ }^{1}$ Department of Agricultural Microbiology, Faculty of Agriculture, Gadjah Mada University, Bulaksumur, Yogyakarta 55281, Indonesia
}

\begin{tabular}{|c|c|}
\hline A R T IC L E I N F O & A B S T R A C T \\
\hline Article history: & Increasing of textile industries creates a critical need for a proper treatment plan to control and \\
\hline Received 27 August 2019 & minimize possibilities of contaminants and toxic compounds being released to the environment. \\
\hline Received in revised form 8 Oct 2019 & Biological approaches by utilizing microorganisms, although because in the rise of practicality and \\
\hline Accepted 9 October 2019 & cost-effectiveness, are still flawed and require more analysis and development. One of such \\
\hline Available online 16 December 2019 & $\begin{array}{l}\text { approach that is often being researched is the utilization of biofilm for treating industrial waste, } \\
\text { and among those is about the use of fungal and bacterial consortium. This research was conducted }\end{array}$ \\
\hline & to examine and acquire a more stable biofilm formed by fungal and bacterial consortium for \\
\hline Keywords : & decolorization process of textile wastewater. Isolates were selected by examining their \\
\hline Teytile wasternater & decolorization capability, antagonistic activity, and mixed culture formation (consortium). The \\
\hline Textile wastewater & selection continued with biofilm forming in material plastic LLDPE. Superior consortium from \\
\hline Vat Violet 1 dye & bacteria and fungi in the form of biofilm in material plastic LLDPE then was applied for the \\
\hline Biofilm & decolorization of Vat Violet 1 dye from textile industrial wastewater. The selection resulted in two \\
\hline Fungal $\quad$. & superior fungal isolates coded as strain JYGC1 and $\mathrm{K} 2$; and three bacterial isolates were coded as \\
\hline Bacterial consortium & $\begin{array}{l}\text { strain ATA6, PK29, and PK65. These isolates were then combined to form biofilm on the surface } \\
\text { of material plastic LLDPE and examined for their applicability to decolorize wastewater } \\
\text { containing Vat Violet } 1 \text { under variation of } \mathrm{pH} \text { condition of } 5,7 \text {, and } 8 \text {. Biofilm with regular } \\
\text { thickness was formed by the fungal bacterial consortium and capable of increasing the rate of } \\
\text { decolorization activity. The highest biomass yield before and after application to the wastewater } \\
\text { was found to be at } \mathrm{pH} 7 \text { at about } 0.66 \mathrm{~g} \text { and } 0.45 \mathrm{~g} \text {, respectively. The thickness and biomass } \\
\text { corresponds with decolorization activity, which is also the highest on pH } 7 \text {, with difference of } \\
1.155 \text { between before and after application; much higher than without biofilm application at } \\
0.714 \text {. }\end{array}$ \\
\hline
\end{tabular}

\section{INTRODUCTION}

According to Selvam et al. [1], there were about 10,000 kind of dyes used in textile industries and $7 \times 10^{5}$ tons dyes produced every year. During the coloring process, $10-15 \%$ of textile dye will be wasted together with industrial textile wastewater. The effluent of dye in industrial textile wastewater is about $60-70 \mathrm{mg} / \mathrm{l}$ ([2]. Besides polluting the environment Mathur et al. [3] stated that the dye also can be harmful to biodiversity and health, such as irritation to skin, eyes, and cause cancer and mutations.

The molecule of dye contains a saturated organic substance combined with chromophore that responsible for its color and auxochrome that intensifies the color of a substance or fibre. Unsaturated organic compound encountered in formation of the dye is generally derived from aromatic compounds and their derivatives (benzene, toluene, xylene, naphthalene, anthracene), phenol and its

${ }^{*}$ Correspondence author.

E-mail : lestari.wevriandini@mail.ugm.ac.id

doi : https://10.21771/jrtppi.2019.v10.no.2.p1-6

2503-5010/2087-0965@ 2018 Jurnal Riset Teknologi Pencegahan Pencemaran Industri-BBTPPI (JRTPPI-BBTPPI).

This is an open acces article under the CC BY-NC-SA license (https://creativecommons.org/licenses/by-nc-sa/4.0/).

Accreditation number : (LIPI) 756/Akred/P2MI-LIPI/08/2016 
derivatives (phenols, ortho/meta/para cresol), and hydrocarbon that is containing nitrogen (pyridine, kinolin, korbazolum) [4].

Chromophore from vat dyes is a carbonyl group. It has an anthraquinone structure with large molecular mass, and the absorption of the fiber is high enough [5]. Vat dyes are also classified as a derivative oxazole included in the anthraquinone dye that is difficult to degrade because of the fused aromatic structures. These dyes are not soluble in water, so that it needs to be reduced using reducing agents such as sodium dithionite. In addition, vat dyes are also carcinogenic and mutagenic in humans [6] [7].

The benefit of bacterial and fungal ability to degrade textile wastewater in remediation allows these two species to grown in the form of a consortium. Consortium of bacteria and fungi is expected to improve the degradation of vat dyes because the complex interactions compounds between two isolates in intracellular or extracellular, such as enzymes in the metabolic process can be more numerous and complex. The use of mixed cultures are more effective in the process of biodegradation of pollutant compounds. In addition, the effectiveness of biodegradation process is also influenced by environmental factors such as $\mathrm{pH}$, temperature, availability of nitrogen and phosphorus. These factors affect the degradation rate [8].

In this study, the formation of a consortium of bacteria and fungi carried out in the form of biofilm. Biofilm can be formed by a single species of bacteria and can also be composed of many species of bacteria, fungi, algae, and protozoa. Biofilms attached to the surface of abiotic or biotic substrate through extracellular polymeric substances (EPS).

Biofilms can be alternatives that are considered safer for bioremediation compared with planktonic microorganisms. It is because the cells in the biofilm are protected in the matrix so that they have a good level of adaptation and survival (especially during periods of stress). The interactions between microorganisms mutually beneficial physically and physiologically in biofilms make possible for the degradation process of xenobiotic compound happens quickly, so in the last few years, biofilm has been used in industrial plants to assist in immobilization and degradation of pollutants [9].

Therefore, consortium of fungi and bacteria in the form of biofilm is possible to increase the degradation of Vat Violet 1 dyes because of the interaction and the production of complex compounds in the metabolic processes. The biofilms formed is expected to be able to decolorize Vat Violet 1 dyes in textile industrial wastewater with higher efficiency levels.

\section{METHODS}

Research was conducted at Laboratory of Agricultural Microbiology, Faculty of Agriculture, Gadjah Mada University, Yogyakarta. Dyes wastewater was obtained from Towel Factory Lumintu 1001, Ngendo, Polanharjo, Klaten, Central Java. Fungal isolates used were coded as TPA4 (Isolated from landfill in Palembang), KRMS5 (Isolated from local sawmills in Palembang), JYGC1 (Isolated from wastewater PT GKBI Sleman, Yogyakarta), K1 (Isolated from purification process of JYGC1), K2 (Isolated from purification process of JYGC1), K3 (Isolated from purification processes of KRMS5). Bacterial isolates used were coded as ATA6 (Bacillus sp.) [10], PJ39 (Isolated from activated sludge PT Pajitex, Pekalongan), PK29 (Isolated from the silt of the river in Pekalongan), and PK65 (Isolated from the silt of the river in Pekalongan).

Plastic material (caps of mineral water bottle) made from LLDPE (Linear Low Density Polyethylene) was used as the material sticking biofilm. It would also require a wire gauze, wire tie, HCL $1 \mathrm{~N}, 1 \mathrm{~N} \mathrm{NaOH}$, and Lactophenol blue (as fungi staining).

The main materials used in this study, include shaker, spectrophotometer UVmini-1240 Shimadzu, pH paper (universal test paper), microscope Nikon SE, Haemacytometer, Petroff-Hauser Bacteria Counter, test tubes, petri dish, centrifuges, Whatman filter paper no $.1 \varnothing$ $125 \mathrm{~mm}$, bunsen burner, microtubes, cuvette, micropipette, microtips, vortex, ose needle, ent needle, drigalski, glass beaker, Erlenmeyer $(125 \mathrm{ml}, 250 \mathrm{ml}, 500 \mathrm{ml})$, measuring 
pipette $(5 \mathrm{ml}$ and $10 \mathrm{ml})$, kimax tubes, glass bottles $(300$ $\mathrm{ml})$ and a digital camera.

Antagonistic activity - Tests performed by KirbyBauer method using paper disc [11]. Each fungal isolates were grown first on a PDA media with a spread plate method and incubated for 2 days. During the growth of fungal isolates, each isolate bacteria was grown on Nutrient Broth (NB) media for 48 hours. Then, it has shaken out with a speed of $125 \mathrm{rpm}$. Furthermore, the sterile paper disc was prepared to be immersed in the bacterial suspension with NB media. Each sterile paper disc soaked about \pm 1 minute and then drained to eliminate excess fluid. Paper disc was placed in petri dish with PDA media and fungal isolate and incubated for 48 hours. The growth of fungal and bacterial isolates is said to inhibit each other if there were formed antagonistic zone around the colonies of bacteria or paper disc. Antagonistic value can be measured by dividing the diameter of antagonistic zone with diameter of bacterial colonies

Table 1. Antagonistic activity value between fungal and bacterial isolates

\begin{tabular}{lcccccc}
\hline & \multicolumn{7}{c}{ Inhibition Zone (mm) } \\
\cline { 2 - 7 } Bacteri & \multicolumn{7}{c}{ Fungi (spread) } \\
\cline { 2 - 7 } a & KRMS & TPA4 & K1 & K & K3 & JYGC \\
PJ39 & 5 & & & 2 & & 1 \\
PK65 & $1.75^{*}$ & $1.10^{*}$ & $1.53^{*}$ & 0 & 0 & 0 \\
PK29 & 1.89 & 1.64 & 1.48 & 0 & 0 & 0 \\
ATA6 & 1.37 & $1.50^{*}$ & $1.47^{*}$ & 0 & 0 & 0 \\
\hline
\end{tabular}

*after day-8 antagonistic activity was stopped

Mixed cultures test - This test is based on methods O'Tolle and Kolter [12], using the medium Basal Glucose Salt (GBS) as a minimal media and media for biofilm formation coupled with tannic acid as an inducer ligninolytic enzyme synthesis. Fungal isolate was put in Erlenmeyer containing $100 \mathrm{~mL}$ GBS media as a starter and incubated for 5 days. Furthermore, the fungal spores were calculated using Haemacytometer $\left(10^{5}\right.$ spores $\left./ \mathrm{ml}\right)$. Fungal spores inoculated into other GBS media $(150 \mathrm{~mL})$ and incubated for 5 days to form clumps of hyphae. During the growth period of fungi, bacteria were grown and incubated as the exponential phase period of bacteria ( 48 hours). The number of bacterial cells with the cell density was calculated using Petroff-Hauser Bacteria Counter $\left(10^{5}\right.$ cells $\left./ \mathrm{ml}\right)$. Once fungal hyphae formed, bacterial isolates were inoculated and incubated at room temperature for 7 consecutive days with $80 \mathrm{rpm}$ of shaking speed. The formation of mixed culture was observed by taking 1 ose inoculant of each culture using microscope with magnification $400 \mathrm{x}$ to $1000 \mathrm{x}$ and stained by lactophenol blue.

Biofilm formation on LLDPE - The formation of biofilm used sterile glass bottles attached with bottle cap made from LLDPE. GBS media and tannic acid $200 \mathrm{~mL}$ inserted into the bottle and then inoculated with fungal and bacterial isolates. Bacterial isolates were inoculated into the bottle after the formation of clumps of fungal hyphae and after the bacteria were incubated for 48 hours at an exponential period. Incubation or biofilm formation was performed for 7 until 14 days at room temperature with speed of shaking about $80 \mathrm{rpm}$. Biofilm formation was observed macroscopically by measuring biomass of biofilm and microscopically.

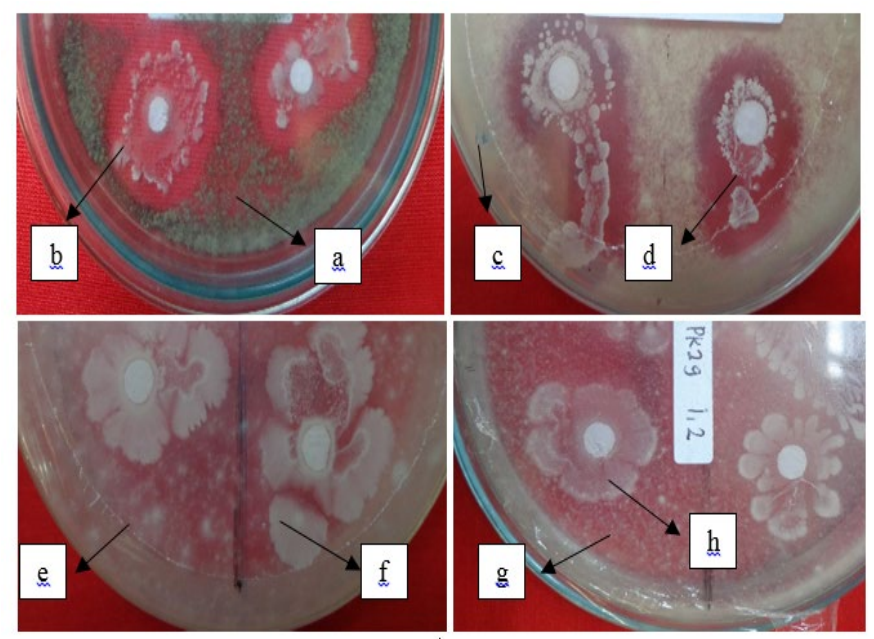

Fig. 1. Growth Inhibition of fungal isolate K1 (a) by bacterial isolate PK65 (b) (left) and fungal isolate TPA4 (c) by bacterial isolate PK65 (d) (right). Growth normally of fungal isolate JYGC1 (e) with bacterial isolate PK29 (f) (left); fungal isolate K2 (g) and bacterial isolate PK29 (h) (right)

Decolorization of Vat Violet 1 dye by biofilm with $p H$ variation - Biofilms formed on the surface of LLDPE weighed prior to application to the Vat Violet 1 
$\left(\mathrm{C}_{34} \mathrm{H}_{14} \mathrm{Cl}_{2} \mathrm{O}_{2}\right)$ dye wastewater. Furthermore, LLDPE material transferred into the bottles that had contained vat violet 1 dye wastewater with three variations of $\mathrm{pH}(5,7$, and 8 ). The cultures were incubated for 14 days at room temperature with speed of shaking about $80 \mathrm{rpm}$. Observations were done every 2 days by measuring the Optical Density (OD) of dye with a wavelength of $312 \mathrm{~nm}$. The wavelength determined by recording the absorbance over some range and the highest absorbance was recorded. Before measuring OD values, vat dyes contain biofilm centrifuged at a speed rate about 12,000 rpm for 5 minutes. Microscopic observation was done by observing the structure of biofilm.

Data Analysis - Data were statistically analyzed using ANOVA test on R software and Microsoft Excel. If there was a significant difference, data was tested further by Duncan's Multiple Range Test (DMRT).

\section{RESULT AND DISCUSSION}

Antagonistic activity value (Table 1) used for selecting the combination isolates (fungi and bacteria that can live together) in the same habitat which in turn could potentially form a mixed culture, or in particular to form biofilms.

Based on antagonistic activity test, selected bacteria and fungi isolate that does not mutually inhibit growth each other was PK29, PK65, PJ39 and ATA6, and K2, K3 and JYGC1. However, further testing, isolate PJ39 were not selected because it low in produce exopolysaccharide (EPS) [13]. Low produce of EPS indicates that the biofilm formation was not formed. K3 also was not selected because it inhibited the growth of ATA6 isolate. Fungal isolates (K2 and JYGC1) and bacterial (PK29, PK65, and ATA6) were tested in the formation of mixed cultures in liquid media.

In the mixed cultures test (Fig. 2) the single culture (fungal isolates only) was found differ with mixed cultures. In single culture, there was no attachment of bacteria on fungal hyphae ((A) and (E)), whereas, in mixed cultures, the bacteria seem to have grown into or attached to fungal hyphae ((B), (C), (D), (F) ; (G), (H)). Attachment of bacteria on fungal hyphae can not be confirmed as a biofilm, nevertheless, it may be the reason that the isolated fungi and bacteria isolates can grow together in the same habitat.

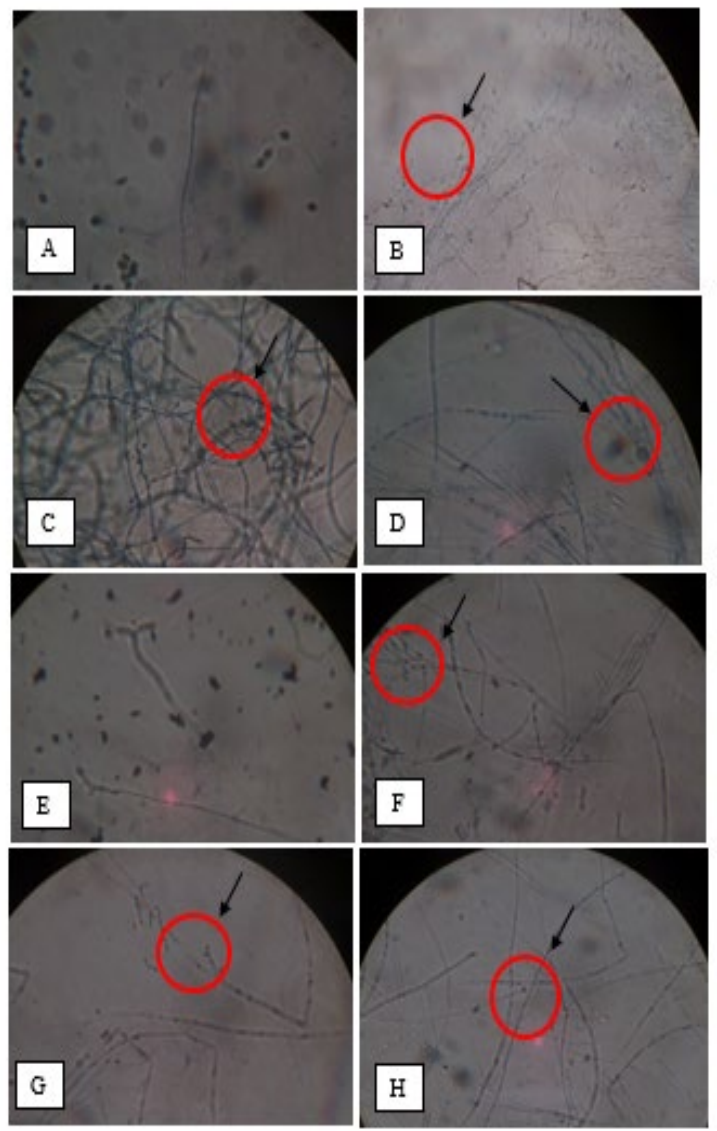

Fig. 2. Microscopically observation mixed culture (zoomed out 400x). (A) Fungal isolate K2; (B) Fungal isolate K2 and bacterial isolate PK29; (C) Fungal isolate K2 and bacterial isolate ATA6; (D) Fungal isolate $\mathrm{K} 2$ and bacterial isolate PK65; (E) Fungal isolate JYGC1; (F) Fungal isolate JYGC1 and bacterial isolate ATA6; (G) Fungal isolate JYGC1 and bacterial isolate PK29; $(\mathrm{H})$ Fungal isolate JYGC1 and bacterial isolate PK65. Arrow showed the attachment of bacteri on fungi hypae

Table 2. Biofilm mass in the surface of LLDPE

\begin{tabular}{cccc}
\hline $\mathrm{pH}$ & \multicolumn{3}{c}{ Biofilm mass $(\mathrm{g})$} \\
\cline { 2 - 4 } & $\mathbf{a}$ & $\mathbf{b}$ & $\mathbf{c}$ \\
\hline $\mathbf{5}$ & 0.56 & 0.36 & $(-) 0.20$ \\
7 & 0.66 & 0.45 & $(-) 0.22$ \\
$\mathbf{8}$ & 0.63 & 0.35 & $(-) 0.27$ \\
\hline
\end{tabular}




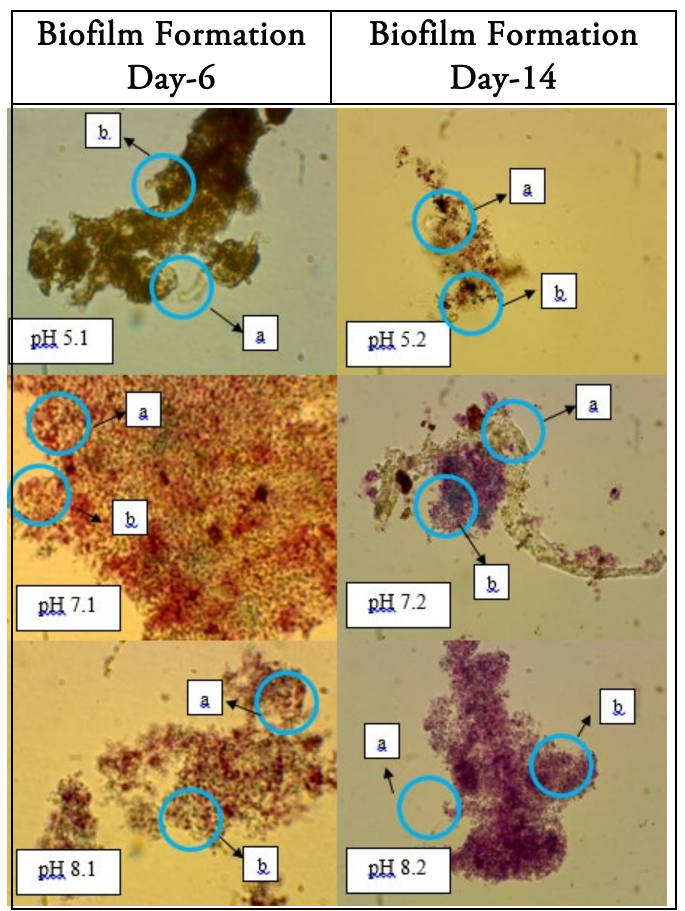

Fig 3. The biofilm formation of bacterial and fungal consortium in the surface of plastic material LLDPE (by microscope, zoomed out 1000x). Fungi (a); bacteria (b)

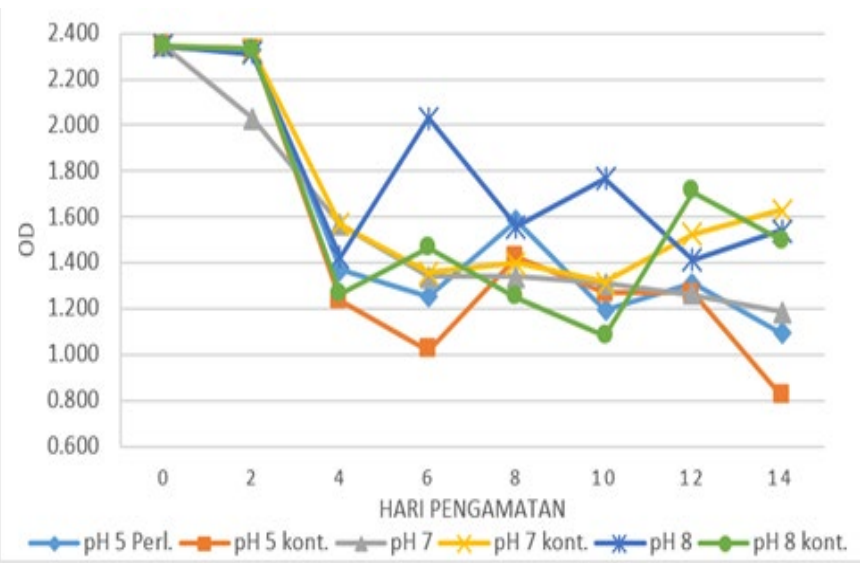

Fig 4. Decolorization of Vat Violet 1 dye wastewater by biofilm of bacterial and fungal consortium in varied $\mathrm{pH}(\mathrm{pH}$ 5, $\mathrm{pH} 7, \mathrm{pH} 8)$.

Biofilm formation was occurred after mixing cultures test using bottle cap (LLDPE material) that has a rough surface. On the inside, there is grooves lid that allows the biofilm to attach in it. Rough surfaces may be a good place for the attachment of biofilm-forming microorganisms [14]. Based on the results (Table 2), the mass of the bottle cap material increased after inoculation fungal and bacterial isolates but decreased after the application into the waste mass.

Biofilm mass after cultures inoculation, but before application to dye wastewater (a); biofilm mass after 14 days application to dye wastewater (b); differences in biofilm mass before and after application to dye wastewater (c).

Biofilm mass reduction was also supported by microscopic examination (Fig. 3) which indicates that biofilms were observed in the microscope is reduced from days or the previous observation. It shows that the mass of biofilms that attached on the surface of plastic material is comparable with density of biofilm that was observed in the microscope.

The application of biofilm in the material LLDPE to decolorize Vat Violet 1 dye on the graph (Fig. 4) shows that the $\mathrm{OD}$ values of dye at all $\mathrm{pH}$ conditions fluctuated, but overall OD values decreased from OD initial starting on the second day of measurement. Impairment OD value of vat dye showed a decrease in the intensity of the dye which also shows the decolorization of dyes by biofilm.

The highest rate of decolorization of vat dye by biofilm at $\mathrm{pH} 7$ with difference at 1.155 between before and after application; much higher than that of without biofilm application at 0.714 . It shows that treatment with biofilm can be an alternative treatment to decolorize Vat Violet 1 dye wastewater. Nevertheless, the ANOVA test results still showed no significant difference between the treatment and control group of decolorization at $\mathrm{pH} 7$ because the calculated $\mathrm{F}$ value was still smaller than the $\mathrm{F}$ table.

\section{CONCLUSION}

Biofilm with regular thickness was formed by the fungal bacterial consortium and capable of increasing the rate of decolorization activity. The highest biomass yield before and after application to the wastewater was found to be at $\mathrm{pH} 7$ at about $0.66 \mathrm{~g}$ and $0.45 \mathrm{~g}$, respectively. The thickness and biomass corresponds with decolorization activity, which is also the highest on $\mathrm{pH} 7$, with difference 
of 1.155 between before and after application; much higher than without biofilm application at 0.714 .

\section{ACKNOWLEDGMENT}

The authors gratefully acknowledge the idea, financial support, and materials in laboratory for Prof. Dr. Erni Martani. All lecturers and students of Microbiology, Faculty of Agriculture, Universitas Gadjah Mada for help and support.

\section{REFERENCES}

Selvam, K., K. Swaminathan, and K. S. Chae. 2003. "Decolourization of azo dyes and a dye industry effluent by a white rot Fungus Thelephora sp." Bioresource Technology 88: 115-119.

Zubaidi, and T. Mutia. 2002. "Decrease the color and loads of wastewater containing disperse dyes using biological mass". Textile Area No 37/II/2002.

Mathur, N., P. Bhatnagar, and P. Bakre. 2005. "Assesing mutagenicity of textile dyes from Pali (Rajasthan) using Ames bioassay”. Apply. Ecol. Environment. Res. 4: 111-118.

Fessenden, B. D. 1994. "Relationship between lignin degradation and production of reduced oxygen species by Phanerochaete chrysosporium”. Appl. Environ. Microbiol. 65: 541-547.

Bhattacharya, S. K., S. Wang, R. V. Angara, T. Kawai, and F. D. Bishop. 1990. Fate and Effect of Azo Dye on an Anaerobic-aerobic System, 44th Purdue Industrial Waste Conference Proceedings. Lewis Publishers Inc., Chelsea, Michigan.

Banat. I. M., P. Nigam, D. Singh, and R. Marchant. 1996. "Microbial decolorization of textile dye-containing effluents: a review. Bioresour”. Technol. 58: 217227.

Gurav, A. A., J. S. Ghosh, and G. S. Kulkarni. 2011. "Decolorization of anthroquinone based dye Vat Red 10 by Pseudomonas desmolyticum NCIM 2112 and Galactomyces geotrichum MTCC 1360". International Journal for Biotechnology and Molecular Biology Research 2: 93-97.

Fritsche. W., and M. Hofrichter. 2008. Aerobic Degradation by Microorganisms. Biotechnology Environmental Processes 11b: 146-155.

Decho, A. W. 2000. "Microbial biofilms in intertidal systems: an overview". Cont. Shelf Res. 20: 12571273.

Khusnuryani, A. 2014. Study of Phenol Degrading Bacteria and Its Ability to Form Biofilms. Sekolah Pasca Sarjana, Universitas Gadjah Mada, Yogyakarta. Disertation.

Hofrichter, M. 2002. "Lignin conversion by Manganese Peroxide (MnP). Enzyme Microbiol”. Technol. 30: 454-466.

Yoshida, S., N. Ogawa, T. Fujii and S. Tsushima. 2009. "Enchanced biofilm formation and 3chlorobenzoate degrading activity by the bacterial consortium of Burkholderia sp. NK8 and Pseudomonas aeruginosa PA01". Journal of Applied Microbiology 106: 790-800.

Faradilla, N. D. 2015. Decolorization of textile industrial waste using consortium biofilm bacteria. Faculty of Agriculture, Universitas Gadjah Mada, Yogyakarta. Thesis.

Denkhaus, E., S. Meisen, U. Telgheder, and J. Wingender. 2006. "Chemical and physical methods for characterization of biofilms". Microchimica Acta 158: 1-27. 